\title{
PENGARUH PROGRAM DANA DESA TERHADAP TINGKAT PARTISIPASI MASYARAKAT DI KECAMATAN GALESONG UTARA KABUPATEN TAKALAR
}

\author{
H. Dahyar Daraba \\ Dosen Lektor Kepala di Institut Pemerintahan Dalam Negeri \\ E-mail: dahyardaraba@gmail.com
}

\begin{abstract}
ABSTRAK:Penelitian ini bertujuan untuk mengetahui dan menganalisis pengaruh program dana desa terhadap tingkat partisipasi masyarakat di Kecamatan Galesong Utara Kabupaten Takalar. Penelitian ini menggunakan pendekatan kuantitatif yang bersifat korelasional. Dengan teknik cluster random sampling diperoleh tiga desa dari Sembilan desa di Kecamatan Galesong Utara yaitu Desa Bontokaddopepe, Desa Tamalate dan Desa Pakkabba sebagai lokasi penelitian. Data diambil dari 55 responden dengan menggunakan kuesioner. Selanjutnya, data dianalisis dengan menggunakan regresi linear sederhana dengan bantuan program SPSS versi 16,00. Hasil penelitian menjelaskan bahwa program dana desa dilaksanakan berdasarkan Rencana Pembangunan Jangka Menengah (RPJM) Desa yang sudah dijabarkan dalam Rencana Kerja Pemerintah (RKP) Desa dan Anggaran Pendapatan Belanja (APB) Desa. Partisipasi masyarakat desa dimulai sejak penyusunan RPJM, RKP Desa, APB (Desa), pelaksanaan pembangunan desa, dan memanfaatkan hasilhasil pembangunan desa. Program dana desa berpengaruh positif dan signifikan terhadap tingkat partisipasi masyarakat desa. Dari persamaan regresi linear sederhana diperoleh informasi bahwa program dana desa mempunyai konstribusi sebesar 0,329 terhadap peningkatan partisipasi masyarakat. Nilai $\mathrm{R}^{2}$ terkoreksi sebesar 0,789 . Nilai ini menjelaskan bahwa sebanyak 78,9 \% variasi yang berbeda dari tingkat partisipasi masyarakat ditentukan oleh program dana desa pada taraf signifikansi $=0,05$.
\end{abstract}

Kata kunci: program, dana desa, tingkat partisipasi, masyarakat.

\section{EFFECT ON THE LEVEL OF VILLAGE FUND PROGRAM COMMUNITY PARTICIPATION IN THE NORTH GALESONG DISTRICT TAKALAR REGENCY}

\begin{abstract}
This research aims to determine and analyze the influence village fund program to the level community participation in the North Galesong District Takalar Regency. This research used a quantitative approach that was correlational. With random cluster sampling technique gained three villages of nine villages in the North Galesong District of Bontokaddopepe Village, this Village and Village Tamalate Pakkabba were the research location. Data taken from 55 respondents using questionnaires. Furthermore, the data were analyzed using simple linear regression with SPSS version 16.00.The results of the research explained the village fund programme implemented based on the Medium Term Development Plan (Plan) Villages that had been outlined in the Government Work Plan (RKP) Village and Budget (APB) Village. The participation of rural communities began RPJM, RKP Village, APB (village), rural development implementation, and it utilised the results rural development. Village fund programme and a significant positive effected on the level of participation rural communities. From simple linear regression equationobtained information the village fund programme had a contribution amounting to 0.329 against public participation. $R^{2}$ value corrected by 0.789 . This value described that as many as $78.9 \%$ of different variations the participation rate $=0.05$.
\end{abstract}

Key words: Program, village fund, level of participation, community.

\section{PENDAHULUAN}

Kemiskinan bukan masalah baru, namun sudah ada sejak masa penjajahan dan sampai saat ini kemiskinan masih menjadi masalah yang belum teratasi. Di negara berkembang seperti Indonesia kemiskinan menjadi masalah utama yang harus diminimalisir, bahkan di negara maju pun masih ada penduduknya yang tergolong miskin. Oleh karena itu, kemiskinan menjadi masalah dunia yang harus diperhatikan.

Sebagai upaya penanggulangan kemiskinan, pemerintah telah melakukan berbagai upaya dalam memberdayakan masyarakat pedesaan. Pemberdayaan masyarakat dipahami sebagai strategi untuk mencapai tujuan meningkatnya kesejahteraan masyarakat terutama keluarga miskin. Melalui proses pembangunan partisipatif, kesadaran kritis dan kemandirian masyarakat, terutama masyarakat miskin dapat ditumbuhkembangkan, sehingga mereka bukan hanya sebagai obyek melainkan juga sebagai subyek dalam upaya penanggulangan kemiskinan.

Pemerintah telah meluncurkan berbagai program untuk membangun pedesaan. Salah satunya adalah program dana desa. Program ini dimulai tahun 2015, dimana di seluruh Indonesia sebanyak 74.093 desa mendapat program tersebut, termasuk desa-desa yang berada di Kecamatan Galesong Utara Kabupaten Takalar. Total dana desa yang disalurkan oleh peme- 
rintah pusat, dalam hal ini kementerian keuangan ke seluruh kabupaten di Indonesia adalah sebesar Rp. 20, 7 trilliun dan mengalami peningkatan tahun 2016 sebesar Rp. 46, 9 trilliun (www.djpk.depkeu.go.id/wp-content/ uploads/03/01.) diakses tgl 4 April 2016).

Tujuan utama dari program tersebut adalah memberdayakan masyarakat dan membangun infrastruktur desa dan tujuan akhirnya adalah kesejahteraan masyarakat. Program Dana Desa sepenuhnya dikelola oleh pemerintah desa dengan melibatkan tokoh-tokoh masyarakat desa mulai dari proses perencanaan, pelaksanaan dan monitoring evaluasi, termasuk persetujuan dari Badan Permusyawaratan Desa (BPD).

Pada sisi lain, walaupun program tersebut telah membantu masyarakat desa dalam penyediaan lapangan kerja dan tingkat pendapatan di desa, tetapi mampukah program tersebut meningkatkan partisipasi masyarakat mulai dari proses perencanaan sampai kepada menjaga atau memelihara hasil-hasil pembangunan di pedesaan.

Untuk tercapainya keberhasilan pembangunan masyarakat desa maka segala program perencanaan, pelaksanaan serta evaluasi pembangunan harus melibatkan masyarakat, karena merekalah yang mengetahui permasalahan dan kebutuhan dalam rangka membangun wilayahnya. Merekalah nantinya yang akan memanfaatkan dan menilai tentang berhasil atau tidaknya pembangunan di wilayah mereka. Tjokroamidjojo (1995:8) menyimpulkan bahwa pembangunan nasional merupakan: (1) proses pembangunan berbagai bidang kehidupan, baik sosial, ekonomi, politik dan lainnya; (2) Proses perubahan sosial yang merupakan proses perubahan masyarakat dalam berbagai kehidupannya ke arah yang lebih baik, lebih maju, dan lebih adil; (3) Proses pembangunan dari, oleh dan untuk masyarakat atau adanya partisipasi aktif masyarakat. Dengan demikian, maka pembangunan itu merupakan proses yang terjadi secara bertahap dan berkelanjutan guna mewujudkan hal yang lebih baik seiring dengan dimensi waktu.

Uraian mengenai pentingnya partisipasi masyarakat dalam perencanaan tersebut sejalan dengan pendapat Conyers (1994) yang lebih lanjut mengemukakan 3 alasan utama mengapa partisipasi masyarakat dalam perencanaan mempunyai sifat sangat penting: (i) partisipasi masyarakat merupakan suatu alat guna memperoleh informasi mengenai kondisi, kebutuhan dan sikap masyarakat setempat, (ii) Masyarakat akan lebih mempercayai program kegiatan pembangunan apabila mereka dilibatkan dalam persiapan dan perencanaannya, karena mereka akan lebih mengetahui seluk beluk program kegiatan tersebut dan akan mempunyai rasa memiliki terhadap program kegiatan tersebut, dan (iii) mendorong partisipasi umum karena akan timbul anggapan bahwa merupakan suatu hak demokrasi bila masyarakat dilibatkan dalam pembangunan.
Sementara itu dari hasil studi pendahuluan diperoleh informasi bahwa masyarakat di Kecamatan Galesong Utara cenderung untuk tidak berpartisipasi dalam pelaksanaan pembangunan terutama tahap perencanaan. Salah satu penyebabnya adalah mereka lebih memilih pergi ke sawah atau melaut karena mereka yakin dengan melakukan pekerjaan tersebut dengan segera akan mendapatkan hasilnya. Sementara ikut dalam kegiatan perencanaan pembangunan desa hanya merupakan kegiatan yang belum pasti mendapatkan hasil untuk memenuhi kebutuhan seharihari mereka. Selain itu, pada tahapan pelaksanaan pembangunan, masyarakat ikut berpartisipasi bekerja jika mereka mendapatkan upah dari apa yang mereka lakukan. Fenomena ini menarik perhatian peneliti untuk mengkaji lebih jauh seperti apa tingkat partisipasi masyarakat desa tersebut pada program dana desa yang telah dikucurkan oleh pemerintah pusat kepada desadesa di Indonesia, khususnya di Kecamatan Galesong Utara Kabupaten Takalar.

Partisipasi masyarakat menjadi entri poin dari penelitian ini mengingat bahwa keberhasilan kedua program tersebut sangat ditentukan oleh seberapa besar tingkat partisipasi masyarakat desa yang bersangkutan yang tidak saja sebagai obyek pembangunan tetapi juga sekaligus sebagai subyek dari pembangunan itu sendiri.Selain itu, partisipasi masyarakat menjadi penting untuk terus dikaji kaitannya dengan programprogram pemerintah yang masuk ke desa karena jangan sampai program-program tersebut hanya menyisakan ketergantungan secara terus menerus tanpa melahirkan kemandirian demikian juga program-program pemerintah yang masuk ke desa memungkinkan hilangnya keswadayaan dan kesukarelaan dari masyarakat. Padahal diketahui bahwa keswadayaan dan kesukarelaan dari anggota masyarakat merupakan bagian dari kearifan lokal yang perlu dikembangkan dan dilestarikan. Intinya adalah bagaimana pemerintahan desa sebagai lembaga lokal mampu meningkatkan partisipasi masyarakatnya, yang oleh Ramadhan P dan Ahmad Buchari (2014:169) menyebut bahwa aktor yang terlibat dalam proses sumber daya organisasi adalah masyarakat lokal yang memiliki kepedulian. Oleh karena itu, permasalahan dalam penelitian adalah bagaimanakah pengaruh pelaksanaan Program Dana Desa terhadap tingkat partisipasi masyarakat di Kecamatan Galesong Utara Kabupaten Takalar?

\section{METODE}

Desain penelitian ini merupakan penelitian korelasional, yang bertujuan untuk mengkaji tingkat partisipasi masyarakat desa pada program dana desa yang dikucurkan oleh pemerintah pusat ke pedesaan. Program Dana Desa baru dimulai dilaksanakan pada tahun 2015. Disain penelitian ini dapat digambarkan sebagai berikut : 


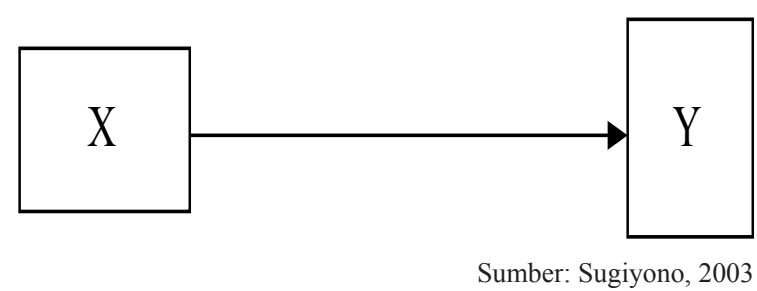

Gambar 1. Desain Penelitian

Aspek-aspek yang diselidiki dalam penelitian ini adalah Program Dana Desa dan Tingkat Partisipasi Masyarakat. Oleh karena itu, variabel penelitian ini adalah pelaksanaan program dana desa (X), sebagai variabel independen dan tingkat partisipasi masyarakat (Y) sebagai variabel dependen.

Definisi operasional variabel penelitian ini adalah sebagai berikut:

1. Program Dana Desa yang dimaksud adalah pelaksanaan program dana desa yang dimulai dari perencanaan, pelaksanaan kegiatan, dan monitoring/ evaluasi di Kecamatan Galesong Utara Kabupaten Takalar.

2. Tingkat partisipasi masyarakat adalah keikutsertaan anggota masyarakat baik pada Program Dana Desa di Kecamatan Galesong Utara Kabupaten Takalar.

Untuk mendapatkan data yang akurat dari penelitian ini, maka sebagai sumber data diambil dari stakeholder yang terkait dengan Program Dana Desa di Kecamatan Galesong Utara Kabupaten Takalar.

Distribusi sumber data dapat dijelaskan sebagai berikut: Kecamatan Galesong Utara terdiri atas 9 desa yaitu Desa Pakkaba, Bontolanra, Aeng batubatu, Tamalate, Tamasaju, Bontosunggu, Aeng Towa, Bontokaddopepe dan Sampulungan. Dengan teknik Cluster random diperoleh tiga desa sebagai sampel penelitian yaitu Desa Pakkabba, Desa Tamalate, dan Desa Bontokaddopepe. Dengan demikian dari tiga desa tersebut masing-masing kepala desanya diambil sebagai sampel sehingga kepala desa berjumlah 3 orang. Demikian juga sekretaris desa dan semua kepala seksi dari ketiga desa tersebut, termasuk bendahara dari masing-masing desa. Pengurus BPD dari masing-masing desa juga diambil sebanyak 3 orang dengan cara random sederhana. Sedangkan untuk unsur masyarakat diambil sampel dengan pertimbangan tertentu yaitu sebanyak 15 orang dari unsur tokoh masyarakat, tokoh agama, tokoh pendidik, tokoh perempuan, dan tokoh pemuda. Oleh karena itu, jumlah sumber data semuanya sebanyak 55 orang termasuk camat, kepala seksi pembangunan dan 2 orang staf pada Kantor Kecamatan Galesong Utara, serta LSM dari 3 desa sampel penelitian.

Untuk menguji hipotesis digunakan teknik analisis regresi linear.Formula regresi linear sederhana yang digunakan adalah sebagai berikut: $\mathrm{y}^{\prime}=\mathrm{a}+$ bX(Sugiyono, 2003).

\section{HASIL DAN PEMBAHASAN}

\section{Pelaksanaan Program Dana Desa}

Program Dana Desa dilaksanakan dengan mengacu kepada empat pilar yaitu bidang pemerintahan desa, bidang pembangunan desa, bidang pemberdayaan desa dan bidang pembinaan kemasyarakatan desa. Paling lama setelah 3 bulan Kepala Desa dilantik maka RPJM Desanya sudah harus selesai. Rencana Pembangunan Jangka menengah Desa (RPJM Desa) harus memuat pola-pola pembangunan yang akan dilaksanakan mulai dari bidang pemerintahan, pembangunan, pemberdayaan, dan pembinaan kemasyarakatan.

Pelaksanaan Program Dana Desa di Kecamatan Galesong Utara Kabupaten Takalar, sudah berlangsung selama dua tahun yaitu tahun 2015 dan 2016. Dalam pelaksanaannya menitikberatkan pada partisipasi masyarakat setempat mulai dari tahap perencanaan, pelaksanaan, pertanggungjawaban, dan bahkan sampai kepada tahap pelestariannya. Uraian pelaksanaan Program Dana Desa di Kecamatan Galesong Utara Kabupaten Takalar disajikan sebagai berikut:

\section{Tahap Perencanaan}

Program Dana Desa di Kecamatan Galesong Utara Kabupaten Takalar dilaksanakan oleh Pemerintah Desa dalam hal ini adalah Kepala Desa dan perangkat desa. Dari tiga desa di Kecamatan Galesong Utara Kabupaten Takalar yang menjadi daerah sampel penelitian menjelaskan bahwa Program Dana Desa dimasukkan ke dalam RPJM Desa dan menitikberatkan kepada empat bidang pembangunan yaitu bidang pemerintahan desa, pembangunan desa, pemberdayaan desa dan pembinaan kemasyarakatan desa.

Rencana Pembangunan Jangka Menengah Desa (RPJM) Desa disusun dengan melibatkan masyarakat desa. Masyarakat desa ikut berpartisipasi menyusun RPJM Desa, memasukkan gagasan-gagasan tentang empat bidang. Di bidang pemerintahan misalnya, para tokoh masyarakat mengusulkan supaya pemerintah desa melakukan pendataan desa. Hal ini dilakukan dengan tujuan mengetahui seberapa jauh capaian-capaian pembangunan desa yang selama ini dilaksanakan. Dari pendataan desa juga diketahui berapa penduduk miskin di desa itu, atau jumlah laki-laki/perempuan untuk kemudian dibuat kelompok-kelompok umur dari masyarakat tersebut. Demikian juga, dengan pendataan desa diketahui jenis-jenis pekerjaan yang dilakukan oleh penduduk desa itu, termasuk tingkat pendidikan yang mereka miliki.

Pada bidang pembangunan, para tokoh masyarakat mengusulkan supaya pemerintah desa membangun jalan desa, rabat beton, sanitasi, pekuburan desa, dan paving blok. Hal ini dilakukan supaya masyarakat di setiap desa tersebut mampu mengakses peluang-peluang untuk memajukan ekonomi mereka dengan cepat. Selain 
itu, di bidang pemberdayaan masyarakat, para tokoh masyarakat mengusulkan supaya ada kegiatan pelatihan usaha ekonomi perdagangan dan usaha ekonomi bidang pertanian. Selain itu, diusulkan pula supaya perangkat desa yang relatif masih baru diberikan pelatihan terkait dengan pengelolaan keuangan desa. Selanjutnya, untuk bidang pembinaan kemasyarakatan, para tokoh masyarakat mengusulkan untuk dilakukan pembinaan kesenian dan budaya masyarakat.

Pemerintah desa dalam upaya menyelenggarakan praktek perencanaan desa melalui tahapan penyusunan RPJM Desa memanfaatkan masyarakat desa terutama yang masih usia muda. Hal ini dimaksudkan supaya dapat memberi masukan atau input-input pembangunan yang dapat dirasakan oleh semua masyarakat di Kecamatan Galesong Utara, tidak hanya masyarakat yang berdagang di pinggir-pinggir jalan poros tetapi juga masyarakat nelayan terutama di Desa Tamalate Kecamatan Galesong Utara Kabupaten Takalar.

\section{Tahap Pelaksanaan}

Pelaksanaan pembangunan desa di Kecamatan Galesong Utara Kabupaten Takalar, periode 2015 sampai dengan 2016 dimotori oleh Pemerintahan Desa. Dana yang mereka kelola, walaupun masih kurang dari satu milyard, tetapi digunakan untuk memakmurkan desa-desa mereka. Warga masyarakat dengan mudah mengakses informasi tentang pelaksanaan pembangunan desa beserta dana-dana yang digunakan. Hampir di setiap kegiatan dibuatkan papan identitas dari program yang dilaksanakan dan memuat mulai dari nama kegiatan, besarnya anggaran biaya yang digunakan sampai kepada waktu penyelesaian dari program tersebut.

Tingginya keterbukaan dalam mengelola kegiatan itu, mengindikasikan tentang tingginya kepercayaan publik kepada pemerintah desa. Transparansi pelaksanaan program dana desa di Kecamatan Galesong Utara Kabupaten Takalar berjalan baik, yang ditunjukkan oleh kerjasama antara Badan Perwakilan Desa dengan Pemerintahan Desa.

Kegiatan pembangunan di desa penelitian melibatkan semua unsur masyarakat desa. Ada unsur pemuda, petani, nelayan, pedagang, dan juga unsur perempuan di desa tempat penelitian berlangsung. Para pemuda dilibatkan dalam kegiatan pembangunan sanitasi desa, petani dilibatkan dalam pembangunan jalan yang menghubungkan antara desa dengan sawah. Terkhusus di Desa Tamalate, para nelayan juga dilibatkan dalam pembuatan tambatan perahu, termasuk jalan paving blok yang menghubungkan rumah-rumah mereka dengan tambatan perahu yang dimaksudkan.

Penggunaan program dana desa di Kecamatan Galesong Utara Kabupaten Takalar, semua dilaksanakan berdasarkan Rencana Kerja Pembangunan Desa (RKP) Desa. RKP Desa yang dimaksudkan tersebut merupakan penjabaran lebih rinci dan mendetail dari RPJM Desa yang disusun untuk operasional satu tahun. Dari RKP desa tersebut disusunlah Rencana Pendapatan dan Belanja Desa untuk satu tahun anggaran.

Dalam pelaksanaan Rencana Anggaran Pendapatan dan Belanja Desa, Pemerintah Desa menyampaikan pemahaman kepada masyarakat desa atas rencana kegiatan yang akan dilaksanakan. Dalam pelaksanaannya, pemerintah desa memberi ruang kepada masyarakat desa untuk pengaduan masalah-masalah yang dapat timbul sebagai akibat dari pelaksanaan anggaran kegiatan yang dimaksudkan.

\section{Tahap Pertanggung jawaban}

Pada tahap pertanggungjawaban program dana desa, pemerintah desa melakukan pertanggungjawaban dari keempat bidang yang menjadi tanggung jawab lokal mereka. Keempat bidang itu adalah bidang pemerintahan desa, bidang pembangunan desa, bidang pemberdayaan desa, dan bidang pembinaan kemasyarakatan desa.

Dalam pelaksanaannya keempat bidang tersebut diuraikan satu persatu dengan memperlihatkan bagianbagian yang dianggap paling sesuai dengan waktu pelaksanaannya, volume, lokasi, dan sasaran yang ditujukan. Untuk bidang penyelenggaraan pemerintahan desa, misalnya dengan menguraikan berdasarkan urutan waktu pelaksanaannya.

Uraian di atas menjelaskan bahwa dana desa di Kecamatan Galesong Utara Kabupaten Takalar dilaksanakan dengan mengacu kepada RPJM Desa. RPJM Desa yang telah disusun oleh masing-masing desa, kemudian dilanjutkan dengan menyusun Rencana Kerja Pembangunan Desa (RKP Desa). RKP Desa tersebut disusun dengan memperhatikan aspek-aspek yang merupakan prioritas untuk dilaksanakan dalam satu tahun anggaran.

Pelaksanaan dana desa tersebut baru diselenggarakan mulai tahun 2015, yaitu sebagai penjabaran UU No. 6 Tahun 2014 tentang Desa. Oleh karena itu, untuk tahun ini baru berjalan selama 2 tahun. Programprogram yang dilaksanakan meliputi empat bidang yaitu bidang penyelenggaraan pemerintahan desa, bidang pembangunan, bidang pemberdayaan masyarakat, dan bidang pembinaan kemasyarakatan desa.

Untuk maksud supaya masyarakat desa dapat mengakses informasi dengan cepat maka melalui program dana desa dibangunlah jalan desa dengan harapan produk-produk desa dapat dengan mudah mengalir dari desa ke desa-desa lainnya atau pun bahkan ke seluruh kawasan pedesaan di Kecamatan Galesong Utara, untuk selanjutnya ke kota. Semua jenis sayur-sayuran sebagai hasil produksi di setiap desa di Kecamatan Galesong Utara Kabupaten Takalar dapat menembus hiruk-pikuk penjualan sayuran di kota. Tidak hanya sayur-sayuran, tetapi juga semua hasil industri rumah tangga juga dengan mudah dapat diakses oleh masyarakat desa termasuk dapat dengan mudah disalurkan ke kota-kota. 
Selain itu, pembangunan rabat beton yang menghubungkan dusun-dusun dalam satu desa juga ditingkatkan. Dengan begitu, tidak hanya produkproduk desa yang mengalami mobilitas yang cepat menuju kota tetapi juga jasa-jasa trampil dari penduduk desa dapat mengalir menuju kota. Tenaga kerja dari desa di Kecamatan Galesong Utara menuju Kota Makassar bertambah banyak sehingga dapat mengurangi tingkat pengangguran terbuka di desa.

\section{Tingkat Partisipasi Masyarakat}

Tingkat partisipasi masyarakat pada tulisan ini diukur dengan menggunakan definisi bahwa partisipasi adalah keterlibatan aktif dari seseorang, atau sekelompok orang (masyarakat) secara sadar untuk berkontribusi secara sukarela dalam program pembangunan dan terlibat mulai dari perencanaan, pelaksanaan, monitoring sampai pada tahap evaluasi. Indikator tingkat partisipasi masyarakat meliputi: mengetahui permasalahan sosial di desanya; menyampaikan saran dalam perencanaan, memberikan masukan sebagai alternatif solusi, memberikan sumbangan berupa barang; memberikan sumbangan berupa keterampilan teknis yang dimiliki; memberikan bantuan tenaga secara sukarela, memanfaatkan hasil pembangunan desa, dan merasa ikut memiliki hasil-hasil pembangunan di desa.

Hasil penelitian menjelaskan bahwa dari 55 responden terdapat 90,91 persen yang mengetahui secara baik tentang tingkat permasalahan sosial di desanya. Selanjutnya untuk item penyampaian saran sebanyak 87,27 persen yang sering menyampaikan saran terkait dengan pengkajian masalah-masalah di desa. Ada 94,55 persen dari responden yang menyampaikan saran sebagai solusi dari permasalahan yang muncul di desa. Sebanyak 78,18 persen dari responden yang menyampaikan bahwa saran-saran mereka itu dijadikan dasar pertimbangan dalam pengambilan keputusan.

Lebih lanjut, berturut-turut terdapat 89,09 persen, 92,73 persen, dan 78,18 persen tentang partisipasi masyarakat dilihat dari pemberian sumbangan baik berupa barang atau alat-alat, keterampilan, dan bahan/ material bangunan seperti tanah timbunan dan pasir yang menjawab sering. Sementara itu, untuk pemberian bantuan tenaga sukarela dari 55 responden terdapat 74,55 persen yang menjawab selalu memberikan tenaga sukarela dalam proses pelaksanaan program pembangunan desa saat Program Dana Desa dilaksanakan. Selanjutnya, untuk hasil-hasil pembangunan di desa seluruh responden menyatakan selalu memanfaatkan dengan baik karena mereka itu merasa ikut memiliki.

\section{Program Dana Desa dan Tingkat Partisipasi Masyarakat}

Hasil uji hipotesis menjelaskan bahwa nilai $\mathrm{t}$ hitung $=2,724$ yang lebih besar dari $\mathrm{t}$ tabel $(0,05$; 2,000 ) atau nilai sig $0,009<0,05$. Hal ini menunjukkan bahwa program dana desa memberikan pengaruh terhadap tingkat partisipasi masyarakat di Kecamatan Galesong Utara Kabupaten Takalar. Program dana desa sudah memberikan konstribusi terhadap tingkat partisipasi masyarakat mulai dari memberikan saran, kritik, bantuan, atau pun terlibat aktif dalam proses pelaksanaan program tersebut.

Model persamaan regresi linear sederhana yang diberikan yaitu $\mathrm{Y}^{\prime}=31,13+0,329 \mathrm{X}$, yang berarti bahwa pelaksanaan program dana desa berkontribusi sebesar 0,329 dalam meningkatkan tingkat partisipasi masyarakat. Pada pelaksanaan program dana desa perlu memperoleh bimbingan dan pendampingan setiap kegiatan terutama mulai pada tahap perencanaan sampai pada tahap pelaporan pertanggungjawaban keuangan dari setiap kegiatan yang dilaksanakan. Hal ini bertujuan agar supaya partisipasi masyarakat tersebut terselenggara dengan baik mulai dari tahap perencanaan sampai kepada pelestarian hasil-hasil pembangunan desa, sekaligus menjamin akuntabilitas pemerintahan desa.

Fokus perencanaan yang berdasarkan masalah dan kebutuhan masyarakat dapat diperoleh melalui kegiatan penyelidikan masalah dan kebutuhan mulai dari tingkat rukun tetangga (RT) yang merupakan bagian dari tahap persiapan dalam proses perencanaan pembangunan. Berdasarkan hasil penelitian, untuk beberapa desa melakukan kegiatan penyelidikan masalah dan kebutuhan masyarakat mulai tingkat RT sehingga diperoleh profil masalah dan kebutuhan masyarakat, namun jenis usulan yang diajukan didiskusikan pada saat pelaksanaan musyawarah dusun, dan digali dari kelompok-kelompok masyarakat.

Perencanaan yang disiapkan sudah mampu memperhatikan aspirasi masyarakat yang memenuhi sikap saling percaya dan terbuka. Hal ini dapat dilihat dari hasil penelitian yang menunjukan bahwa pelibatan masyarakat dilakukan pada tingkatdusun yang artinya hanya perwakilan masyarakat yang terlibat dalam proses perencanaan pembangunan dan juga dilibatkan dalam penetapan daftar prioritas masalah dan kebutuhan dusun yang akan disampaikan pada proses perencanaan pembanggunan (musrenbang) Desa. Partisipasi masyarakat dimana setiap masyarakat memperoleh peluang yang sama dalam sumbangan pemikiran tanpa dihambat oleh kemampuan berbicara, waktu dan tempat, serta masyarakat dilibatkan dalam memutuskan kegiatan mana yang dianggap prioritas untuk diajukan ke musrenbang yang lebih tinggi.

Jika dilihat dari dokumen sebagai bahan masukan dalam proses perencanaan pembangunan tingkat desa, sudah tersedia beberapa kelengkapan seperti: daftar prioritas permasalahan/kegiatan desa/kelurahan, dan daftar prioritas masalah di tingkat desa.

Dalam aspek legalitas, perencanaan dimana perencanaan pembangunan dilaksanakan dengan mengacu pada semua peraturan yang berlaku, menjunjung 
etika dan tata nilai masyarakat. Proses perencanaan pembangunan di Kecamatan Galesong Utara Kabupaten Takalar dilaksanakan sudah sesuai dengan petunjuk teknis musrenbang. Partisipasi masyarakat dalam perencanaan pembangunan memberikan banyak manfaat bagi masyarakat itu sendiri, diantaranya meningkatkan kemampuan masyarakat melalui pelaksanaan program pembangunan, agar kondisi kehidupan masyarakat mencapai tingkat kemampuan yang diharapkan, memberi kekuasaan atau mendelegasikan kewenangan kepada masyarakat agar masyarakat memiliki kemandirian dalam pengambilan keputusan untuk membangun diri danlingkungannya. Dengan demikian upaya melibatkan masyarakat dalam perencanaan dan pelaksanaan pembangunan berarti memampukan dan memandirikan masyarakat.

Geddesian (dalam Soemarmo 2005:26) mengemukakan bahwa pada dasarnya masyarakat dapat dilibatkan secara aktif sejak tahap awal penyusunan rencana, begitupun kaitannya dengan pelaksanaan perencanaan pembangunan di Kecamatan Galesong Utara Kabupaten Takalar. Keterlibatan masyarakat dapat berupa: (i) pendidikan dan pelatihan, melalui pendidikan dan pelatihan untuk masyarakat Kecamatan Galesong Utara belum dilakukan secara menyeluruh, pendidikan mengenai perencanaan pembangunan hanya diberikan kepada kader yaitu sejumlah orang sebagai wakil dari setiap desa, (ii) partisipasi aktif dalam pengumpulan informasi. Partisipasi aktif masyarakat dalam pengumpulan informasi belum dilaksanakan secara menyeluruh di Kecamatan Galesong Utara, hanya sebagian kecil khususnya para tokoh masyarakat, tokoh pemuda, dan tokoh perempuan yang dilibatkan, (iii) partisipasi dalam memberikan alternatif rencana dan usulan kepada pemerintah. Dalam prakteknya, sebagian besar masyarakat memberikan alternatif rencana dan usulan kepada pemerintah desa, meskipun alternatif rencana dan usulan yang disampaikan belum memenuhi sifat spesifik, terukur dan dapat dijalankan.

Menurut Alexander Abe (2002) menyatakan bahwa ada dua bentuk perencanaan partisipatif, yaitu: Pertama, perencanaan yang langsung disusun bersama masyarakat, perencanaan ini bisa merupakan: (a) perencanaan lokasi setempat, yakni perencanaan yang menyangkut daerah dimana masyarakat berada; (b) perencanaan wilayah yang disusun dengan melibatkan masyarakat secara perwakilan. Kedua, perencanaan disusun melalui mekanisme perwakilan, sesuai dengan institusi yang sah (legal formal), seperti parlemen. Untuk yang kedua ini, masyarakat sebaiknya masih tetap terbuka dalam memberikan masukan, kritik dan kontrol, sehingga apa yang dirumuskan dan diaktualisasikan oleh parlemen benar-benarapa yang dikehendaki oleh masyarakat.

Jika dilihat dari proses perencanaan dalam rangka Program Dana Desa di Kecamatan Galesong Utara, maka yang dilaksanakan merupakan bentuk pertama, dimana perencanaan disusun langsung oleh bersama masyarakat, walaupun untuk sebagian desa masih belum melibatkan semua lapisan masyarakat dalam proses perencanaan pembangunan terlebih dalam proses identifikasi masalah dan kebutuhan masyarakat.

Perencanaan yang disusun bersama masyarakat adalah suatu proses dimana masyarakat bisa langsung ikut ambil bagian. Menurut Alexander Abe (2002), untuk mengorganisasi perencanaan model ini perlu diperhatikan prinsip dasar yang penting dikembangkan, yakni:(i) dalam perencanaan bersama rakyat, yang melibatkan banyak orang, maka harus dipastikan bahwa diantara para peserta memiliki rasa saling percaya, saling mengenal dan bisa saling bekerja sama, (ii) pelaksanaan rembug RT, prinsip ini secara keseluruhan belum dilaksanakan di Kecamatan Galesong Utara, dimana peserta yang hadir adalah orang yang biasa dikenal sehari-hari dalam lingkungan RT (mereka adalah tokoh masyarakat) sehingga perasaan saling percaya, saling mengenal dan bisa saling bekerja sama tentunya ada, tetapi belum melibatkan semua warga rukun tetangga, (iii) agar semua orang bisa berbicara dan mengemukakan pandangannya secara fair dan bebas, maka diantara peserta tidak boleh ada yang lebih tinggi dalam kedudukan, kesetaraan menjadi penting.Poin ini sudah dilaksanakan dengan baik. (iv) perencanaan bersama rakyat harus bermakna bahwa rakyat (mereka peserta perumusan) bisa menyepakati hasil yang diperoleh, baik saat itu maupun setelahnya. Harus dihindari praktek perang intelektual, dimana mereka yang berkelebihan informasi mengalahkan mereka yang miskin informasi secara tidak sehat, (iv) Suatu keputusan yang baik, tentu tidak boleh didasarkan pada dusta atau kebohongan. Prinsip ini hendak menekankan pentingnya kejujuran dalam penyampaian informasi, khususnya persoalan yang sedang dihadapi, (v) berproses berdasarkan kepada fakta, dengan sendirinya menuntut cara berpikir yang obyektif. (vi) prinsip partisipasi hanya akan mungkin terwujud secara sehat, jika apa yang dibahas merupakan hal yang dekat dengan kehidupan keseharian masyarakat.

Jika dilihat dari proses perencanaan dan pelaksanaan Program Dana Desa di Kecamatan Galesong Utara Kabupaten Takalar, prinsip dasar di atas sebagian sudah dikembangkan, terutama prinsip partisipasi masyarakat akan terwujud secara sehat, jika apa yang dibahas merupakan hal yang dekat dengan kehidupan keseharian masyarakat desa (Anonim, 2016).

Selain itu, perlu ada peningkatan tingkat partisipasi masyarakat desa dalam setiap perencanaan pembangunan desa mulai dari tahap sosialisasi, penyusunan RPJM Desa, RKP Desa dan pelestarian hasil-hasil pembangunan desa untuk semua lapisan masyarakat dan semua stakeholders yang lain serta didukung oleh adanya pendamping kegiatan. Hasil ini juga mendukung temuan dari Dahyar D (2015: 171) bahwa keberhasilan beberapa kelompok usaha bersama (KUBE) di Kecamatan Polongbangkeng 
Utara Kabupaten Takalar karena didukung oleh para pendamping kegiatan yang profesional.

\section{SIMPULAN}

Pelaksanaan Program Dana Desa berpengaruh positif dan signifikan terhadap tingkat partisipasi masyarakat desa. Dana Desa dilaksanakan dengan mengacu kepada Rencana Pembangunan Jangka Menengah (RPJM) Desa yang telah dijabarkan dalam Rencana Kerja Pemerintah (RKP) Desa dan Anggaran Pendapatan Belanja (APB) Desa. Partisipasi masyarakat dimulai dari perencanaan, pelaksanaan, sampai kepada pelestarian hasil-hasil pembangunan desa baik dalam bentuk pemberian saran, bantuan barang, tenaga, dan ikut memanfaatkan hasilhasil pembangunan di desa.

\section{DAFTAR PUSTAKA}

Alexander, A, 2002. Perencanaan Daerah Partisipatif, Penerbit Pondok Edukasi, Solo.

Anonim. 2016. Kebijakan Dana Desa dan ADD-2016 Kemenkeu.pdf. (www.djpk.depkeu.go.id/wpcontent/uploads/03/01. Diakses 4 April 2016.
Conyers, D, 1994, Perencanaan Sosial di Dunia Ketiga: Suatu Pengantar, Gadjah Mada Yogyakarta: University Press.

Dahyar D, 2015. Faktor-Faktor Yang Mempengaruhi Keberhasilan Program Pemberdayaan Masyarakat Miskin di Kecamatan Polongbangkeng Utara Kabupaten Takalar Provinsi Sulawesi Selatan, Sosiohumaniora, 17 (2), 168-171.

Ramadhan P dan Buchari, A. 2014. Model Kelembagaan Pengelolaan Air Bersih Berbasis Partisipasi Masyarakat di Kawasan Kaki Gunung Manglayang. Sosiohumaniora. 16 (2), 165-170.

Soemarmo, 2005, Analisis Pelaksanaan Pendekatan Partisipatif Pada Proses Perencanaan Pembangunan Di Kota Semarang (Studi Kasus Pelaksanaan Penjaringan Aspirasi Masyarakat Di Kecamatan Banyumanik), Tesis, Magister Administrasi Publik, Universitas Diponegoro, Semarang.

Sugiyono, 2003, Statistisika Untuk Penelitian, Penerbit: CV Alfabeta. Bandung.

Tjokroamidjojo, B. 1995, Manajemen Pembangunan, Gunung Agung, Jakarta. 